\title{
In-Vitro Antibacterial and Antifungal Efficacy of Greenly Fabricated Senna alata Leaf Extract Silver Nanoparticles and Silver Nanoparticle-Cream Blend
}

\author{
Bukola Christianah Adebayo-Tayo ${ }^{1 *}$, Samuel Oluwadara Borode, Solomon Omoniyi Alao \\ ${ }^{1}$ Industrial Microbiology and Biotechnology Unit, Department of Microbiology, Faculty of Science, University of Ibadan, \\ 200284 Ibadan, Oyo State, Private Bag 5116, Nigeria \\ * Corresponding author, e-mail: bukola.adebayo@mail.ui.edu.ng
}

Received: 28 March 2012, Accepted: 28 May 2021, Published online: 03 January 2022

\begin{abstract}
Nanoparticles biosynthesis has been extensively studied for its biomedical applications. In this study, the in-vitro antibacterial and antifungal activity of greenly fabricated silver nanoparticles (NPs) from Senna alata leaf extract (SaAgNPs) and silver nanoparticle cream blend (SaAgNPs-cream blend) were investigated. The SaAgNPs were characterized using UV-visible spectrophotometry, FTIR, SEM, TGA, DLS, EDX, and XRD. The presence of surface plasmon band around $500 \mathrm{~nm}$ indicates AgNPs formation and functional groups such as alkenes, carboxylic acids, and alkyl aryl ether responsible for capping and stabilization of the nanoparticles. The SaAgNPs were spherical and $1.00 \mu \mathrm{m}$ in size; TGA shows the formation of stable SaAgNPs, DLS shows $1.8 \%$ intensity with $1905 \mathrm{~nm}$ average diameter and a polydispersity index of 0.595. EDX analysis confirmed the formation of pure silver nanoparticles. SaAgNPs supported the production of cosmetically acceptable SaAgNPs-cream blend with appropriate pH and viscosity. SaAgNPs and the SaAgNPs creamblends had antibacterial activity against all and some of the test bacterial and fungal isolates. SaAgNPs had the highest activity against Pseudomonas aeruginosa 27853, Rhizopus sp. and Candida tropicalis with a zone of $16 \mathrm{~mm}$ and $30 \mathrm{~mm}$. The cream-blends had activity against $68.75 \%$ and $75 \%$ of the test bacteria and fungi with the highest activity against Streptococcus epidermidis B (7.0 mm) and Candida albicans B $(8.0 \mathrm{~mm})$. In conclusion, the crude Senna alata leaf extracts, the bio-fabrication SaAgNPs and SaAgNPs-cream blend have antibacterial antifungal potentials which can be effectively utilized for the control of pathogenic bacteria and fungi.
\end{abstract}

Keywords

Senna alata, bio-fabrication, silver nanoparticles, antibacterial, antifungal, cream-blend

\section{Introduction}

Resistance to antibiotics and outbreak of infectious diseases by emergence and reemergence pathogens has been on the high side and this has constituted a problem to global health. There is a growing concern about the emergence of Multi-Drug Resistant (MDR) pathogens with their impact on the global economy and preventive medicine system. MDR pathogens are listed among the top three threats to public health by the World Health Organization (WHO) [1]. This problem has necessitated researchers and pharmaceutical companies in search of novel broad-spectrum antimicrobials. The use of antimicrobial agents has been described as one of the satisfying forms of chemotherapy used tremendously for the treatment of communicable diseases [2]. Research has been geared toward the use of nanotechnology in search of and to develop new antimicrobials with a high spectrum of activity to tackle the existence of resistance strains, emergence, and reemergence pathogens.

Nanotechnology is an emerging technology that deals with nano-scale structures starting from approximately $1-100 \mathrm{~nm}$ in a minimum of one dimension. Antibacterial applications of nanotechnology are growing rapidly and the use of metal nanoparticles (NPs) as an alternative to antibiotics is on the increase. The combination of biosynthesis and nanoparticles is a new ground to fight and prevent infectious agents by applying nano-scale materials [3]. The green chemistry approach has caught the attention of Scientists and this has become an active part of recent nanobiotechnological research [4].

Silver is a noble metal with unique properties such as good electrical conductivity, high antimicrobial efficiency, catalytic activity, and chemical stability [5]. It has been 
extensively applied in the various biomedical fields, agriculture, textile, and water industries. Silver has application as antimicrobials in ionic, nanoscale, and bulk metallic forms [6]. Silver nanoparticles have been considered as essential metal nanoparticles with good characteristics and diverse applications in various fields and the production of different new products. Investigation into nanosilver may proffer a solution to the problem of multidrug resistance, emergence, and reemergence pathogens [7].

The green approach of nanoparticle biosynthesis through bio-reduction and stabilization of noble metals by metabolites from microorganisms and bioactive compounds from plants is on the increase and is gaining interest in biomedical application. Biosynthesis of different metal-based nanoparticles using microbial metabolites and plant phytochemicals for various applications has been reported [8]. The leaf extracts of Azadirachta indica, Atrocarpus altilis, Mussaenda glabrata and Myrtaceae family have been used for the biosynthesis of silver nanoparticles [9-13].

Senna alata is a medicinal plant commonly known as Asunwon, emperor's candlesticks, and candle brush tree $[14,15]$. It is a medicinal plant from the family Leguminosae and subfamily Fabaceae and it has various applications in traditional medicine [16]. The roots, leaves, and flowers of Senna alata possess diverse phytochemical components with biological properties such as antibacterial, antifungal, antitumor, expectorant, insecticidal, anti-inflammatory, hydragogue, sudorific, diuretic, pesticidal potentials [17-21].

The plant extracts have been traditionally used for the treatment of skin infections, pityriasis versicolor, and hymenolepisdiminuta, for alleviation of asthma symptoms, internally as an expectorant for bronchitis, as a laxative to expel intestinal parasites, for stomach problems, and weight loss [16, 22-26]. Senna alata fresh leaf juice has been reported to be useful for the treatment of ringworm, snakebite, scorpion bite, skin diseases, impetigo, syphilis sores, itching, mycosis (washerman's itch), herpes, and eczema [27]. Biological evaluation of phytochemicals coated silver nanoparticles using aqueous extract of leaves of Cassia alata has been reported by Vijayakumari and Sinthiya [27]. The antimicrobial mechanism through enhancement of bacterial membrane degradation of ecofriendly synthesized Senna alata silver nanoparticles has been reported [28]. Different parts of the plant are used for the preparation of herbal remedies with antimicrobial properties. This preparation may be in form of cream, lotion, soap, sap, solvent extracts, and ointment which has been reported to contain antimicrobial properties [29]. Topical application of cream through the skin has been a promising concept as a result of easy penetration, large surface area, and easy contact with the circulatory and lymphatic system in association with the non-invasive nature of the cream. Senga et al. [30], reported an herbal dermal ointment formulation from whole leaves of Cassia alata Linn. Development and evaluation of antimicrobial herbal formulations containing the methanolic extract of Cassia alata for skin diseases have been reported [31]. There is a dearth of information on the antibacterial and antifungal potential of Senna alata silver nanoparticle and silver nanoparticle-cream blend. The antiseptic property of Cassia alata-based herbal soap against skin pathogens has been reported [32]. The study aimed at fabrication and characterization of silver nanoparticles using Senna alata leaf extracts through green chemistry approach, production of Senna alata silver nanoparticle-cream blend, and evaluation of in-vitro antibacterial and antifungal potential of the fabricated silver nanoparticles and the Senna alata silver nanoparticle-cream blend.

\section{Materials and methods}

\subsection{Collection of plant}

The leaves of Senna alata were collected from the premises of the University of Ibadan. Silver nitrate $\left(\mathrm{AgNO}_{3}\right)$ was obtained from Sigma-Aldrich Chemicals Germany.

\subsection{Extraction of plant extract}

The collected leaves were air-dried and then milled. This was then poured into a macerating jar and then methanol was added and filled to the brim. The solvent was then stirred with the solute using a well-sterilized glass rod and this was repeated every 8 hours which lasted for 72 hours. After 72 hours of extraction, the extract was decanted and filtered using a Whatman's filter paper (No.1). This was then concentrated using a rotary evaporator under reduced pressure and low temperature.

\subsection{Production and characterization of silver nanoparticles}

\subsubsection{Biosynthesis of Silver Nanoparticles (AgNPs)}

The crude methanol leaf extract of Senna alata was used for the biosynthesis of silver nanoparticles. $100 \mathrm{~mL}$ of $1 \mathrm{mM}$ aqueous solution of silver nitrate $\left(\mathrm{AgNO}_{3}\right)$ was prepared in $250 \mathrm{~mL}$ Erlenmeyer flasks and $40 \mathrm{~mL}$ of the dissolved crude methanol Senna alata leaf extract was added into the conical flasks for the bioreduction of the silver 
nitrate $\left(\mathrm{AgNO}_{3}\right)$ into silver $\left(\mathrm{Ag}^{0}\right)$. This composite was observed for colour changes and then later placed in an incubator for the complete bioreduction at a temperature of $37^{\circ} \mathrm{C}$ for 24 to 72 hours.

\subsubsection{Characterization of the greenly fabricated SaAgNPs}

The $\mathrm{SaAgNPs}$ were characterized using visual observation, UV-Vis spectroscopy, Fourier-Transform infrared spectroscopy, scanning electron microscopy, thermogravimetric analysis (TGA), dynamic light scattering (DLS), energy-dispersive X-ray spectroscopy (EDX), and X-ray diffraction (XRD).

Visual observation of the reaction mixture during biosynthesis was done and colour changes were noted.

The bio-reduction of silver nitrate solution for $\mathrm{SaAgNPs}$ biosynthesis was monitored by measuring the optical density of the reaction mixture through UV-Vis spectroscopy. Analysis was done using UV-Vis spectrophotometer (Ocean Optics, USA). $2 \mathrm{~mL}$ of the sample suspension was collected after $72 \mathrm{hrs}$ to monitor the completion of the bio-reduction of the nanoparticles in an aqueous solution. Subsequent scan in UV-Visible spectra, between a wavelength of $200-800 \mathrm{~nm}$ at a resolution of $1 \mathrm{~nm}$. The UV-Vis spectra were recorded after $72 \mathrm{hrs}$.

FTIR was used for the determination of the functional groups responsible for the bio-reduction of $\mathrm{Ag}^{+}$to $\mathrm{Ag}^{0}$. The analyses of the dried SaAgNPs were carried out using the potassium bromide ( $\mathrm{KBr}$ ) pellet (FTIR grade) method in a ratio of 1:100. FTIR spectroscopy (Shimadzu) was used to record the spectrum at the wavelength between $400-4500 \mathrm{~cm}^{-1}$ and resolution of $4 \mathrm{~cm}^{-1}$.

Scanning electron microscopy (SEM) analysis was carried out using the JEOL machine for SEM. A thin film of dried SaAgNPs powder sample was coated on a coater (JEOL, Akishima-shi, Japan, and Model No. JFC-1600). The images of NPs were eventually obtained in an SEM. The information concerning the applied voltage, magnification, and image contents sizes was also implanted on the images.

The thermo-stability of the dried SaAgNPs samples was determined using TGA instruments. Samples were placed in $100 \mu \mathrm{L}$ ceramic pans and equilibrated to $28^{\circ} \mathrm{C}$ in the TGA, and then heated at a rate of $40-600{ }^{\circ} \mathrm{C}$ per minute. During the sample measurement, the air was introduced to the samples at a rate of $50 \mathrm{~mL} / \mathrm{min}$ to maintain an oxidizing environment around the sample [33]. The residue was used to estimate the silver content in the SaAgNPs.

Particle size distribution and the average size of SaAgNPs were obtained using a particle size analyzer. The samples were diluted and analyzed using DLS (Malvern Zetasizer, Nano Z500 UK) and the sample holder temperature was set at $25^{\circ} \mathrm{C}$.

The EDX spectroscopy was used to determine the elemental composition of the SaAgNPs. The homogenized and well pelletized dried samples were used and pure silver was used as standard. Oxford instruments analytical EDX analysis software was used.

XRD analysis was carried out using a Siemens Kristalloflex diffractometer operating at $45 \mathrm{kV}$ with a current of $40 \mathrm{~mA}$ using nickel-filtered $\mathrm{Cu}-\mathrm{K} \alpha$ radiation from 4 to $70^{\circ}$ ( $2 \theta$ angle).

\subsection{Production of SaAgNPs-cream blend}

The SaAgNPs-cream blend was prepared according to the method of Adebayo-Tayo et al. [34]. The greenly fabricated SaAgNPs were mixed with the aqueous phase. The reaction mixture was homogenized properly and the oily phase was aseptically added. The mixture was stirred properly until a semisolid cream blend was formed. Cream base without the addition of SaAgNPs was used as control.

The physicochemical parameters ( $\mathrm{pH}$ and viscosity) of the fabricated silver nanoparticles cream blend were analyzed. The $\mathrm{pH}$ was determined using a digital $\mathrm{pH}$ meter [35]. The viscosity was determined using Brookfield viscometer $\mathrm{DV}-\mathrm{II}+$ pro with spindle type 7 at room temperature of $25^{\circ} \mathrm{C}$. The spindle was rotated at 50 and 100 RPM (Revolutions Per Minute).

\subsection{Determination of the in-vitro antibacterial and antifungal potential of the fabricated SaAgNPs and SaAgNPs-cream blend}

The antibacterial and antifungal potential of the fabricated $\mathrm{SaAgNPs}$ and the SaAgNPs-cream blend were tested using the Agar Well Diffusion method [36]. Wells were bored on previously seeded Mueller Hilton agar plates. $100 \mu \mathrm{L}$ of SaAgNPs, SaAgNPs-cream blend, and the control samples were dispensed into the wells. The inoculated plates were incubated at $35{ }^{\circ} \mathrm{C}$ for 24 and 72 hours for bacteria and fungi respectively. Dimethyl sulfoxide (DMSO), streptomycin, fungusol (Miconazole Nitrate B.P. $2 \%$ ), and silver nitrate were used as control. The antibacterial and antifungal activities were then determined by measuring the diameter of the zones of inhibition in millimeters $(\mathrm{mm})$.

\subsection{Minimum Inhibitory Concentration (MIC) determination}

The MIC of the SaAgNPs was determined using the agar well method. A sterile cork borer $(8 \mathrm{~mm})$ was used to bore 
wells on seeded plates. SaAgNPs at different concentrations from $10100 \%$ were dispensed into each well. The preparation was left to diffuse before incubating at $37^{\circ} \mathrm{C}$ and $28^{\circ} \mathrm{C}$ for 24 and $72 \mathrm{hrs}$ for bacteria and fungi respectively. The lowest concentration of SaAgNPs that completely prevented the growth of the test isolates was taken as the MIC of the SaAgNPs.

\section{Results and discussion}

\subsection{Visual observation of the SaAgNPs}

The visual observation of the greenly synthesized SaAgNPs is shown in Fig. 1. A change in colour of the reaction mixture from pale green to brown indicated the formation of silver nanoparticles.

Recently Nanoparticles have attained great interest because of their unique physical and chemical properties. UV-visible absorption spectroscopy is broadly being utilized as a technique to determine the optical properties of nanosized particles. The formation of SaAgNPs could be easily monitored by a change in color from pale green to brown colour. Silver nanoparticle synthesized, initially observed by a colour change from pale green to brown was further confirmed by UV-visible spectroscopy. The generation of dark brown color is due to the surface plasmon resonance (SPR) exhibited by the SaAgNPs [37].

\subsection{UV-Vis spectrophotometry analysis of the SaAgNPs} UV-Vis absorption spectrum of greenly synthesized SaAgNPs after 72 hours of incubation is shown in Fig. 2. The absorption spectrum was recorded for the nanoparticles in the range of $200-800 \mathrm{~nm}$. The surface plasmon resonance (SPR) peak was observed at $500 \mathrm{~nm}$, which corresponds to silver nanoparticles biosynthesis.

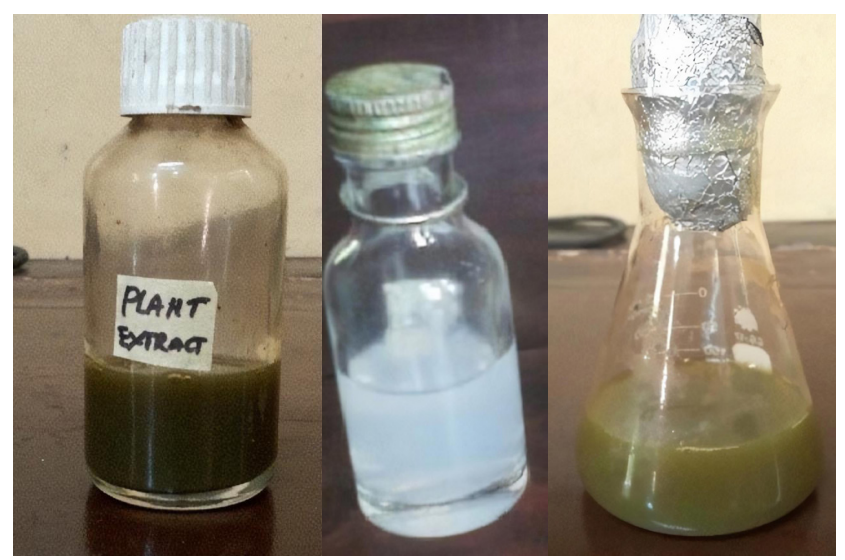

(a)

(b)

(c)

Fig. 1 Visual observation of biosynthesized silver nanoparticles; (a) Senna alata crude methanol leaf extract; (b) Silver nitrate;

(c) Biosynthesized silver nanoparticles

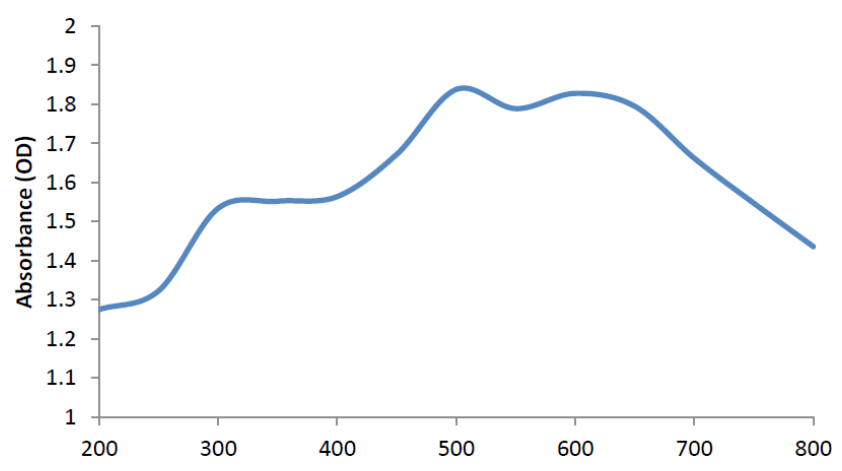

Fig. 2 UV-Vis spectra of silver nanoparticles biosynthesized using crude methanol leaf extract of Senna alata

SaAgNPs showed maximum absorbance at $500 \mathrm{~nm}$ after 74 hours of incubation, which implies that bioreduction of $\mathrm{Ag}^{+}$to $\mathrm{Ag}^{\mathrm{o}}$ has taken place following incubation of the extract with $\mathrm{AgNO}_{3}$. A surface plasmon peak of $550 \mathrm{~nm}$ was reported by Adebayo-Tayo et al. [38] during the biosynthesis of Citrus aurantifolia silver nanoparticles. Balashanmugam et al. [39] reported a peak at $430 \mathrm{~nm}$ for Cassia roxburghii mediated silver nanoparticles. Krishnaraj et al. [40] reported the absorption spectrum of silver nanoparticles produced by Azadirata indica leaf extract presents a maximum peak at $420 \mathrm{~nm}$.

The reduction of silver nitrate by plant extracts occurs through the oxidation of the amino group or some alkaloids or terpenoids present in this plant by the transfer of electrons from the functional group of the bioactive compounds to the $\mathrm{Ag}^{+}$ions. This plant extract can then passivate the surface of silver nanoparticles and stabilize the nanoparticles produced owing to the coordination of nitrogen atoms or some other groups with $\mathrm{Ag}^{0}$ atoms at the surface of SaAgNPs. The resulting metallic silver nucleates gradually to form SaAgNPs and further stabilizes it electrostatically [41, 42].

Bioactive components of plants were reported to be responsible for the bio-reduction of silver ions to silver nanoparticles [43].

\subsection{FTIR analysis of the SaAgNPs}

The FTIR spectrum of the greenly synthesized SaAgNPs is shown in Fig. 3.14 peaks were present between $3937 \mathrm{~cm}^{-1}$ to $453 \mathrm{~cm}^{-1}$. The FTIR spectrum showed a broad peak at $3435 \mathrm{~cm}^{-1}$ which corresponds to the stretching vibrations of the hydroxyl $\mathrm{OH}$ band. The peak at $2103 \mathrm{~cm}^{-1}$ indicates an alkyne $\mathrm{C} \equiv \mathrm{C}$ bending vibration. The peaks at $1643 \mathrm{~cm}^{-1}$, $952 \mathrm{~cm}^{-1}, 903 \mathrm{~cm}^{-1}$ and $710 \mathrm{~cm}^{-1}$ showed the stretching vibrations of alkenes $(C=C)$ group. Furthermore, the peak at $1437 \mathrm{~cm}^{-1}$ indicates the presence of the carboxylic acid (O-H) group. The peak at $1318 \mathrm{~cm}^{-1}$ indicates the presence 


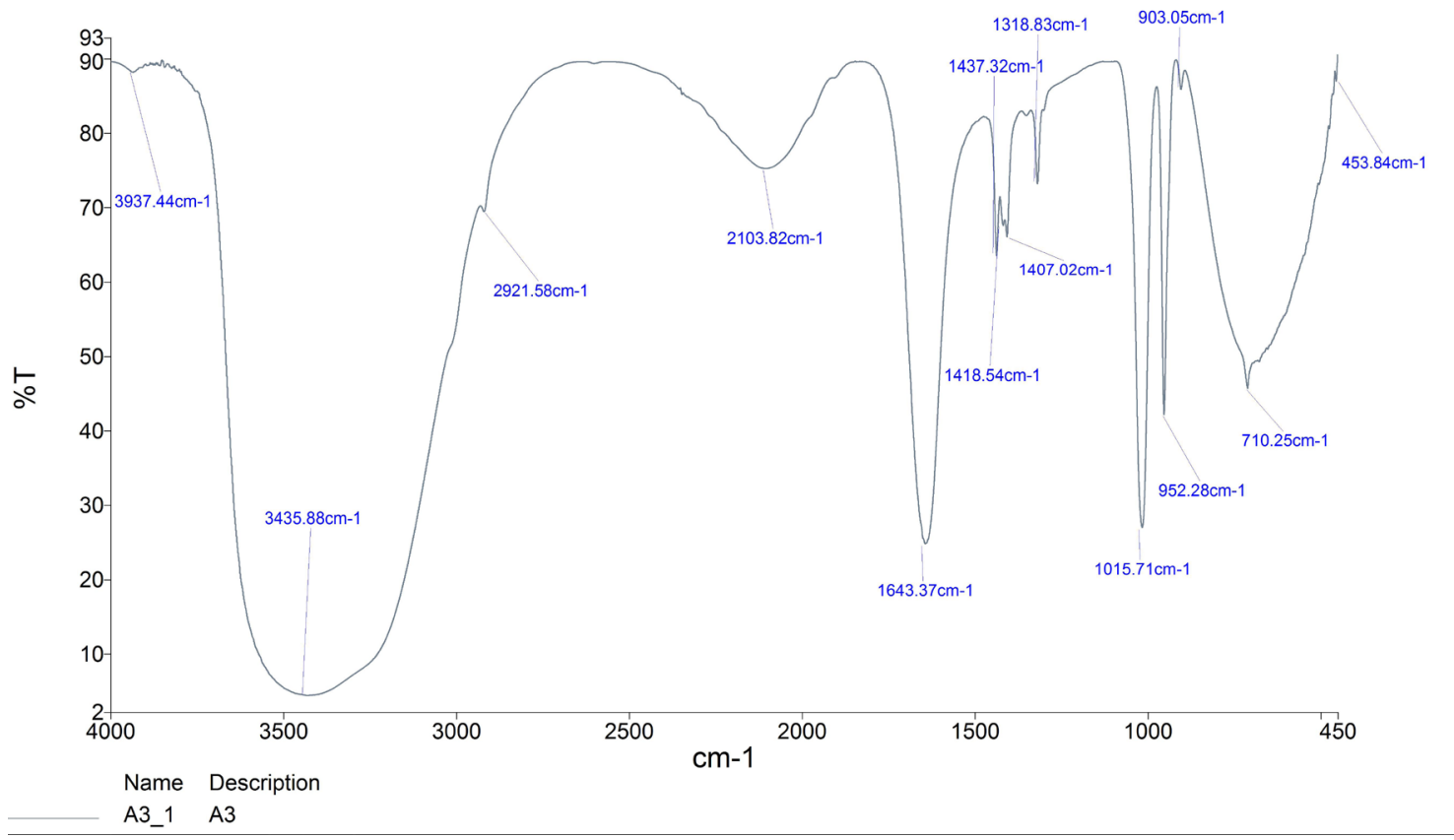

Fig. 3 FTIR spectra of silver nanoparticles biosynthesized using crude methanol leaf extract of Senna alata

of phenol; tertiary alcohol. The band at $1015 \mathrm{~cm}^{-1}$ corresponds to the bending vibration of alkyl aryl ether (C-O), while the peak at $1418 \mathrm{~cm}^{-1}$ shows the presence of an alcohol O-H group.

The FTIR spectra of the biosynthesized silver nanoparticles using Senna alata leaf extract showed different peaks which represents the functional groups of bioprecursor responsible for bio-reduction of $\mathrm{Ag}^{+}$. These functional groups have a strong ability to bind with reduced non-ionic Ag metal to prevent agglomeration and to stabilize nanoparticles in the medium.

Possible functional groups like primary and secondary proteins, alcohols, ethers, carboxylic acids, esters, and anhydrides have been reported for silver nanoparticles of Cassia auriculata leaf extract [44].

\subsection{SEM analysis of the SaAgNPs}

SEM micrograph of greenly synthesized SaAgNPs is shown in Fig. 4. The SaAgNPs are spherical in shape with an average diameter of $10.2 \mathrm{~nm}$.

The spherical shape to irregular shape with agglomeration and $10 \mathrm{~nm}$ size of the nanoparticles was evidenced by SEM images. Sintubin et al. [45] reported silver nanoparticles biosynthesized from plants, algae, yeasts, fungi, and bacteria exhibited varied sizes and shapes.

\subsection{TGA analysis of the SaAgNPs}

The thermogravimetric analysis of the greenly synthesized SaAgNPs is shown in Fig. 5. The TGA profile shows a continuous weight loss with two quasi-sharp changes occurring

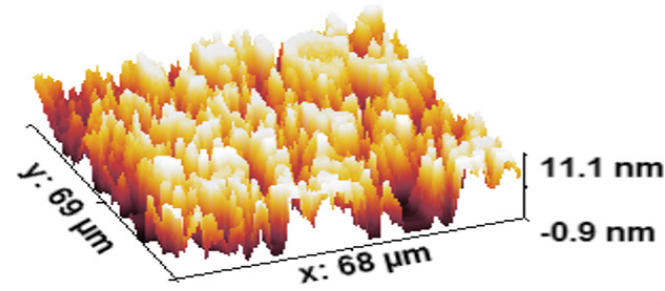

Fig. 4 3D scanning electron micrograph of silver nanoparticles biosynthesized using crude methanol leaf extract of Senna alata

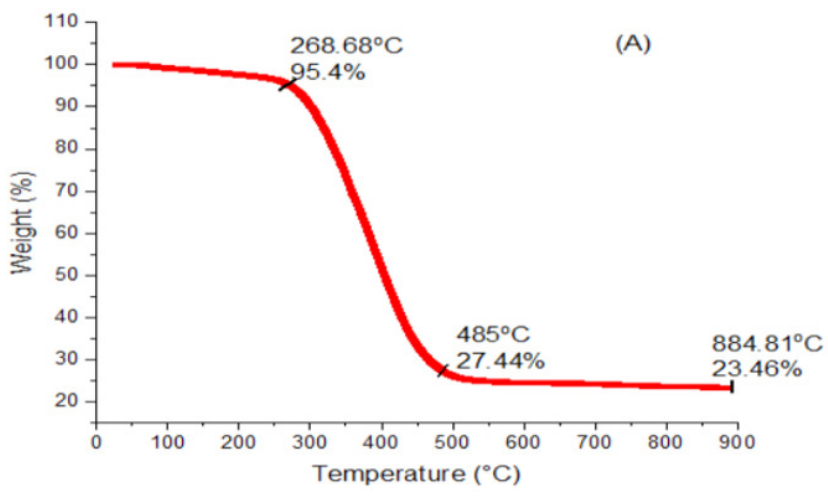

Fig. 5 Thermogravimetric analysis of silver nanoparticles biosynthesized using crude methanol leaf extract of Senna alata

at $268.68{ }^{\circ} \mathrm{C}$ and $485^{\circ} \mathrm{C}$ followed by a nearly constant plateau. The annealing above $400{ }^{\circ} \mathrm{C}$ seems to guarantee the formation of stable SaAgNPs. After heating to $268.68{ }^{\circ} \mathrm{C}$, the excess water seems to be driven off and the material initiates organic carbon decomposition. Oxidation of the catalyst particles is seen after $485^{\circ} \mathrm{C}$, leading to dramatic mass changes with a residual mass of $23.46 \%$ at $884.81{ }^{\circ} \mathrm{C}$. 
The two stages of weight loss by SaAgNPs during TGA analysis indicate the decomposition and vaporization of various functional groups at different temperatures. The large weight loss may be attributed to the breakdown of the organic carbon coordinated with silver nanoparticles in the extract- $\mathrm{AgNO}_{3}$ hybrid. Deshmukh et al. [46] recorded a two-stage weight loss in both silver and iron oxide nanoparticles biosynthesis. When the temperature reached $884.81{ }^{\circ} \mathrm{C}$ the weight of the hybrid remained at $23.46 \%$. TGA shows NP-stabilizes interaction and confirmation of the stabilizer type. The report is in line with the report of Singh et al. [47], that the TGA of nanoparticles and capping agents not only provides information about the stability of nanoparticles but can also evaluate the yield of nanoparticles in the final product.

\subsection{DLS analysis of the SaAgNPs}

Average particle size, size distribution, and polydispersity index (PDI) of the greenly synthesized SaAgNPs were measured using dynamic light scattering (Fig. 6). Two hydrodynamic diameters were present in the SaAgNPs with an average particle size of $855.4 \mathrm{~nm}$ and $89.70 \mathrm{~nm}$ respectively.

The hydrodynamic diameter using the diffusion coefficient of SaAgNPs colloids and the autocorrelation function measured using dynamic light scattering techniques showed the size and distribution of the NPs.
The large average diameter $1905 \mathrm{~nm}$ of the SaAgNPs can be attributed to the aggregation of the nanoparticles over time. This is in line with the work of Chitsazi et al. [48] who observed an increase in the average diameter of synthesized nanoparticles with an increase in reaction time.

\subsection{EDX analysis of the SaAgNPs}

Fig. 7 reports the EDX spectrum of the greenly synthesized SaAgNPs is shown in Fig. 7. The spectrum of the optimized sample confirmed the presence of silver in the powder. The appearance of other elements is attributed to grid support. Consequently, there are no other elements except silver, other elements present are as a result of interference from the sample bottle.

The EDX spectrum of the SaAgNPs sample confirmed the presence of silver in the sample, which clearly shows the purity of the greenly synthesized silver nanoparticles [49, 50].

\subsection{XRD analysis of the SaAgNPs}

The XRD pattern based on the face-centered cubic structure of Bragg reflection index of the SaAgNPs is shown in Fig. 8. The XRD pattern showed three notable peaks at $2 \theta$ values of $20.31^{\circ}, 36.45^{\circ}$, and $79.09^{\circ}$, and can be indexed as (100), (111) and (311) planes of the face-centered cubic (FCC) structure, respectively. The crystallite size was observed as $8.66 \mathrm{~nm}$ at a $2 \theta$ angle of $79.09^{\circ}$.

$\begin{array}{lll}\text { Size (d.n... } & \text { \% Intensity: } & \text { St Dev (d.n... } \\ 855.4 & 98.2 & 114.6 \\ 89.70 & 1.8 & 8.597 \\ 0.000 & 0.0 & 0.000\end{array}$

Result quality Refer to quality report

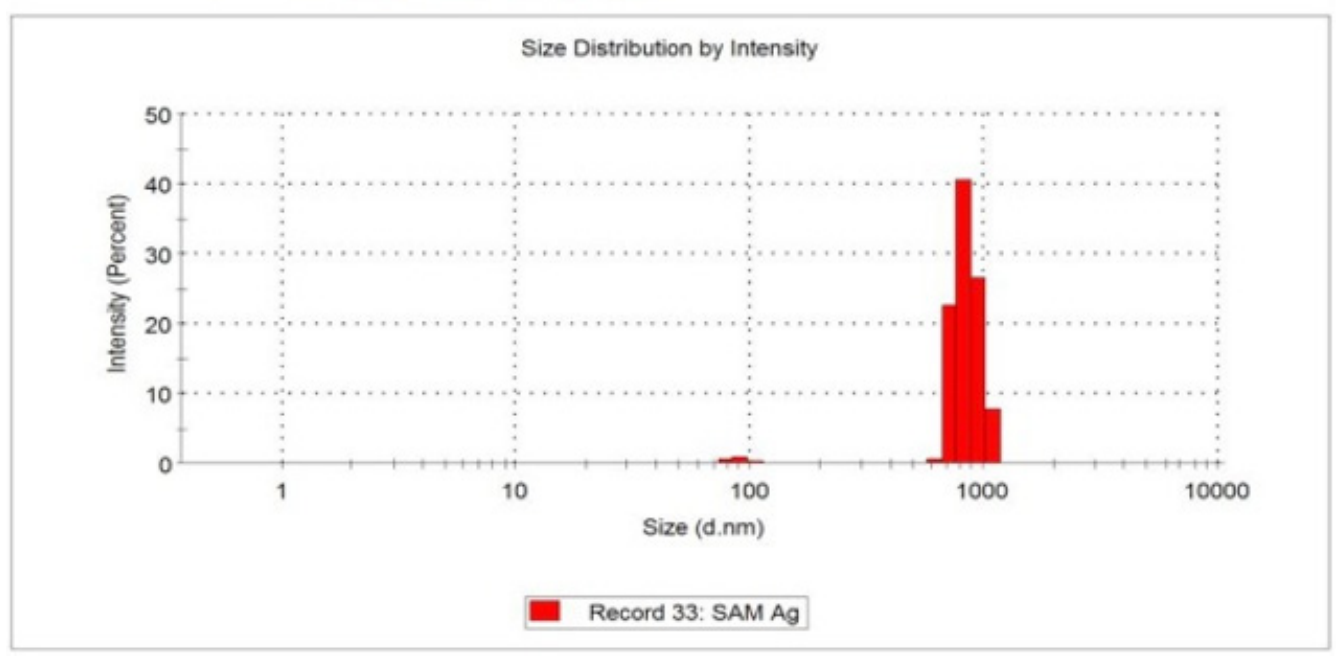

Fig. 6 Dynamic light scattering showing the particle size distribution of silver nanoparticles biosynthesized using crude methanol leaf extract of Senna alata 


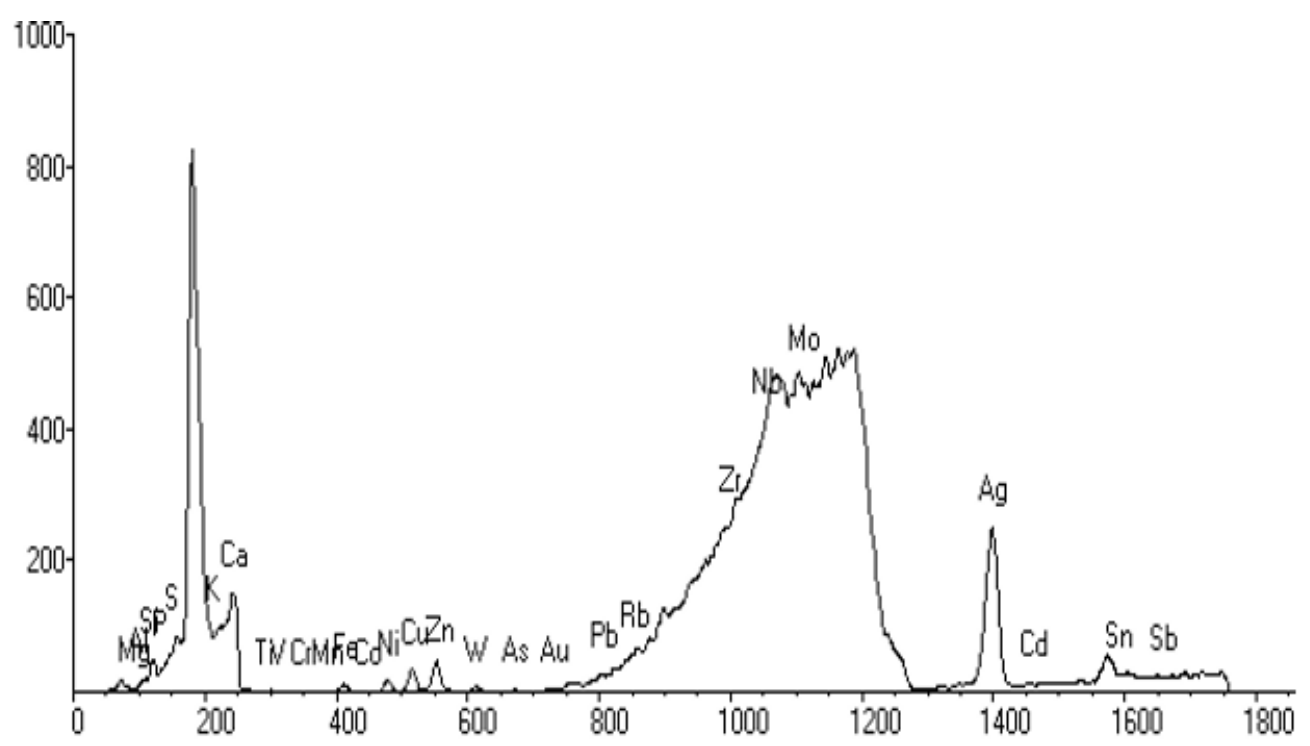

Fig. 7 EDX spectrum of silver nanoparticles biosynthesized using crude methanol leaf extract of Senna alata

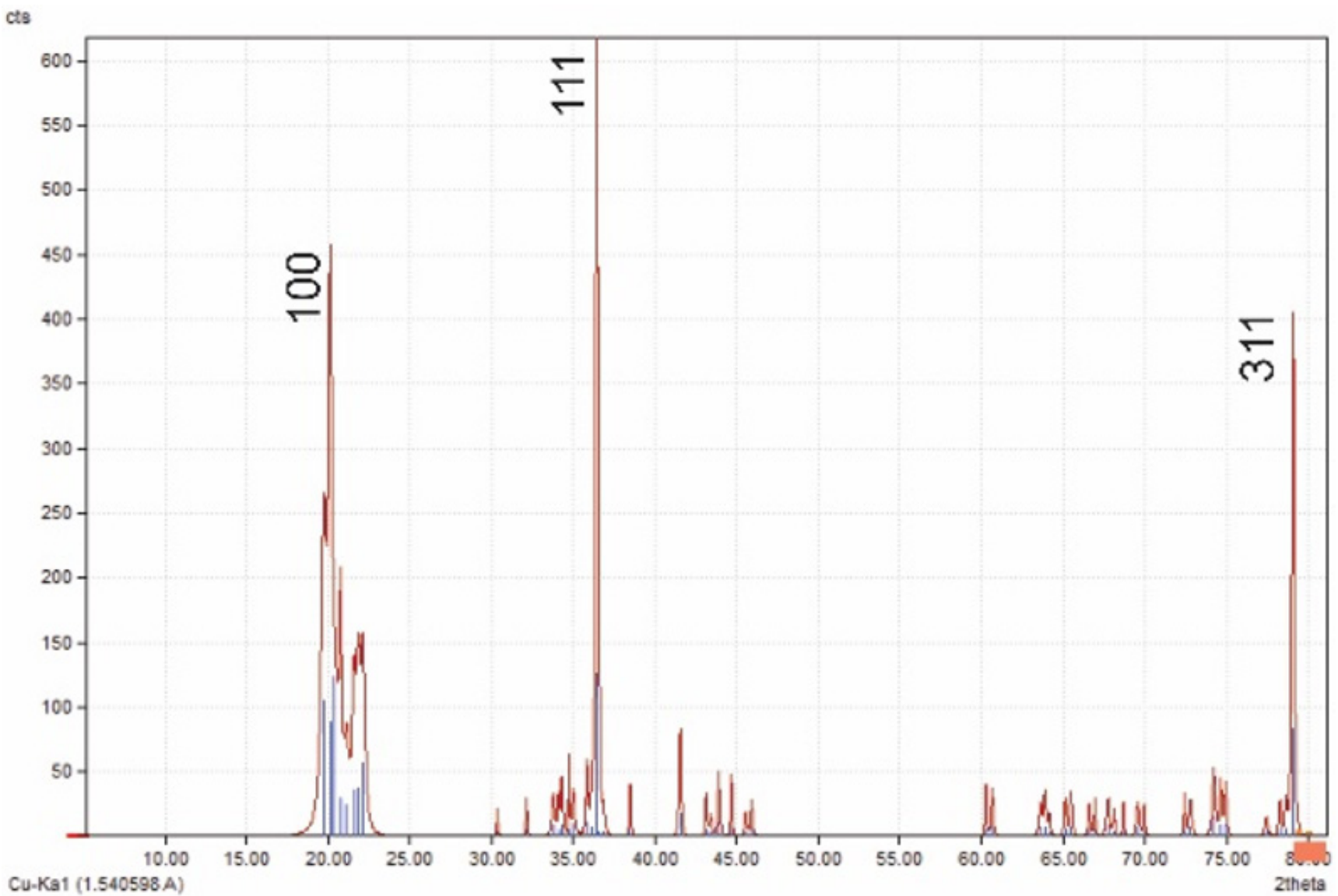

Fig. 8 XRD pattern of silver nanoparticles biosynthesized using crude methanol leaf extract of Senna alata

\subsection{Antibacterial activity of the SaAgNPs}

3.9.1 Determination of the antibacterial activity of the SaAgNPs

The antibacterial activity of the greenly synthesized SaAgNPs is shown in Table 1. SaAgNPs had antibacterial activity against all the test bacterial isolates.
The antibacterial activity ranged from $8.0-16.0 \mathrm{~mm}$. Pseudomonas aeruginosa 27853 had the highest susceptibility follow in order by Staphylococcus aureus A and B and Staphylococcus saprophyticus A with a zone of $14.0 \mathrm{~mm}$. The least antibacterial activity was against Staphylococcus aureus C, Staphylococcus aureus 29213, 
Table 1 Antibacterial activity of SaAgNPs against some test bacteria

\begin{tabular}{|c|c|c|c|c|c|}
\hline \multirow{2}{*}{$\mathrm{S} / \mathrm{N}$} & \multirow{2}{*}{ Test Bacteria } & \multicolumn{4}{|c|}{ Zone of inhibition (mm) } \\
\hline & & $\mathrm{SaAgNPs}^{*}$ & $\mathrm{AgNO}_{3}^{* * *}$ & Streptomycin ${ }^{* * * *}$ & DMSO \\
\hline 1 & Staphylococcus aureus A & 14.0 & 8.0 & 8.00 & - \\
\hline 2 & Staphylococcus aureus B & 14.0 & 8.0 & 9.50 & - \\
\hline 3 & Staphylococcus aureus $\mathrm{C}$ & 8.0 & 6.0 & 12.50 & - \\
\hline 4 & Staphylococcus aureus D & 10.0 & 4.0 & 12.00 & - \\
\hline 5 & Staphylococcus aureus 29213 & 8.0 & 4.0 & 7.00 & - \\
\hline 6 & Eschericia coli 35218 & 8.0 & 2.0 & 7.00 & - \\
\hline 7 & Eschericia coli 11775 & 12.0 & 4.0 & 6.50 & - \\
\hline 8 & Pseudomonas aeruginosa 27853 & 16.0 & 6.0 & 7.00 & - \\
\hline 9 & Citrobacter freundii & 8.0 & 2.0 & 8.00 & - \\
\hline 10 & Salmonella typhi 14028 & 8.0 & 2.0 & 7.00 & - \\
\hline 11 & Bacillus cereus & 10.0 & 3.0 & 7.50 & - \\
\hline 12 & Staphylococcus saprophyticus A & 14.0 & 8.0 & 8.50 & - \\
\hline 13 & Staphylococcus saprophyticus B & 12.0 & 4.0 & 8.00 & - \\
\hline 14 & Staphylococcus epidermidis A & 10.0 & 4.0 & 8.00 & - \\
\hline 15 & Staphylococcus epidermidis B & 12.0 & 4.0 & 8.00 & - \\
\hline 16 & Staphylococcus epidermidis C & 10.0 & 3.0 & 6.50 & - \\
\hline
\end{tabular}

* SaAgNPs - Silver nanoparticles biosynthesized with Crude methanol leaf extract of Senna alata;

** $\mathrm{AgNO}_{3}$ - Silver nitrate;

*** Streptomycin - Antibacterial drug

Eschericia coli 35218, Citrobacter freundii, and Salmonella typhi 14028.

$\mathrm{AgNO}_{3}$ and streptomycin had antibacterial activity against the test bacterial isolates. Staphylococcus aureus A and Staphylococcus aureus C and D had the highest susceptibility (8.0 and $12.0 \mathrm{~mm})$.

The antibacterial activity of the SaAgNPs against all the tested bacteria pathogen is in line with the work of Sarsar et al. [51] who reported the antibacterial activity of silver nanoparticles of Penicillium atramentosum. Antibacterial activity may be due to the loss of activity during DNA replication. It has been hypothesized that the expression of ribosomal subunit proteins, as well as some other cellular proteins for ATP synthesis, becomes inactivated [52].

\subsubsection{Determination of the antifungal activity of the SaAgNPs}

The antifungal potential of the greenly synthesized SaAgNPs is shown in Table 2. All the test fungal strains were susceptible to the SaAgNPs. The antifungal activity ranged from 9.0-30.0 $\mathrm{mm}$. The highest antifungal activity was against Rhizopus sp. and Candida tropicalis follow in order by Candida albicans $\mathrm{C}$. The least antifungal activity was against Candida albicans A with a zone of $9.0 \mathrm{~mm}$.

The test fungi were more susceptible to $\mathrm{AgNO}_{3}$ solution than the commercial antifungal agent. Candida albicans $\mathrm{C}$ had the highest susceptibility to $\mathrm{AgNO}_{3}$ solution with the antifungal activity of $18.0 \mathrm{~mm}$ while Candida albicans B had the least susceptibility $(4.0 \mathrm{~mm})$. Candida albicans $\mathrm{C}$ and Pichia sp. had the highest susceptibility $(8.0 \mathrm{~mm})$ to fungusol. Candida krusei and Candida albicans A had the least susceptibility with a zone of $2.0 \mathrm{~mm}$.

The antifungal potential of the greenly synthesized SaAgNPs showed that the nanoparticles were effective as an antimicrobial agent in the control of pathogenic fungi such as Candida albicans and Candida tropicalis. Balashanmugam et al. [39] and Mallmann et al. [53] also reported the antifungal activity of silver nanoparticles against fungi.

\subsection{MIC of the SaAgNPs}

The Minimum Inhibitory Concentration of the greenly synthesized SaAgNPs against pathogenic bacteria is shown in Table 3. SaAgNPs showed activity against Staphylococcus aureus A, Staphylococcus aureus B, Salmonella typhi 14028, Bacillus cereus, and Staphylococcus epidermidis A up to $10 \%$ concentration. The MIC for Pseudomonas aeruginosa 27853 was at $30 \%$ SaAgNPs concentration.

The Minimum Inhibitory Concentration (MIC) of SaAgNPs against pathogenic fungi is shown in Table 4. The silver nanoparticles had activity against 3 fungal strains; Rhizopus sp, Candida tropicalis, and Candida krusei at $30 \%$ concentration. 
Table 2 Antifungal activity of SaAgNPs against some pathogenic fungi

\begin{tabular}{lccccc}
\hline \multirow{2}{*}{$\mathrm{S} / \mathrm{N}$} & \multirow{2}{*}{ Test Fungi } & \multicolumn{2}{c}{ Zone of inhibition $(\mathrm{mm})$} & \multicolumn{2}{c}{ Control $(\mathrm{mm})$} \\
\cline { 3 - 6 } & & SaAgNPs $^{*}$ & $\mathrm{AgNO}_{3}{ }^{* *}$ & Funguso $^{* * * *}$ & DMSO \\
\hline 1 & Candida albicans $\mathrm{A}$ & 9.0 & 7.0 & 2.0 & - \\
2 & Candida albicans $\mathrm{B}$ & 14.0 & 4.0 & 6.0 & - \\
3 & Candida albicans $\mathrm{C}$ & 28.0 & 18.0 & 8.0 & - \\
4 & Rhizopus sp. & 30.0 & 16.0 & 4.0 & - \\
5 & Pichia sp. & 10.0 & 6.0 & 8.0 & - \\
6 & Candida tropicalis & 30.0 & 17.0 & 4.0 & - \\
7 & Candida krusei & 10.0 & 6.0 & 2.0 & - \\
8 & Trichophyton interdigitale & 14.0 & 10.0 & 6.0 & - \\
\hline
\end{tabular}

* SaAgNPs - Silver nanoparticles biosynthesized with Crude methanol leaf extract of Senna alata;

$* * \mathrm{AgNO}_{3}-$ Silver nitrate;

*** Fungusol - Miconazole Nitrate B.P. $2 \%$

Table 3 MIC of SaAgNPs against selected pathogenic bacteria

\begin{tabular}{|c|c|c|c|c|c|c|}
\hline \multirow{3}{*}{ Test Bacteria } & \multicolumn{6}{|c|}{$\%$ MIC for SaSNPs } \\
\hline & \multicolumn{6}{|c|}{ Zone of inhibition (mm) } \\
\hline & 100 & 90 & 70 & 50 & 30 & 10 \\
\hline $\begin{array}{l}\text { Staphylococcus } \\
\text { aureus A }\end{array}$ & 14.0 & 17.0 & 15.0 & 10.0 & 9.0 & 8.0 \\
\hline $\begin{array}{l}\text { Staphylococcus } \\
\text { aureus B }\end{array}$ & 14.0 & 9.0 & 9.0 & 9.0 & 8.0 & 5.0 \\
\hline $\begin{array}{l}\text { Staphylococcus } \\
\text { aureus } \mathrm{C}\end{array}$ & 8.0 & 6.0 & 4.0 & 5.0 & 2.0 & - \\
\hline $\begin{array}{l}\text { Staphylococcus } \\
\text { aureus D }\end{array}$ & 10.0 & - & - & - & - & - \\
\hline $\begin{array}{l}\text { Staphylococcus } \\
\text { aureus } 29213\end{array}$ & 8.0 & 4.0 & 3.0 & 4.0 & 1.0 & - \\
\hline Eschericia coli 35218 & 8.0 & 4.0 & 4.0 & 2.0 & - & - \\
\hline Eschericia coli 11775 & 12.0 & 4.0 & 4.0 & 3.0 & - & - \\
\hline $\begin{array}{l}\text { Pseudomonas } \\
\text { aeruginosa } 27853\end{array}$ & 16.0 & 12.0 & 14.0 & 12.0 & 9.0 & - \\
\hline Citrobacter freundii & 8.0 & 4.0 & 3.0 & 2.0 & - & - \\
\hline $\begin{array}{l}\text { Salmonella typhi } \\
14028\end{array}$ & 8.0 & 6.0 & 8.0 & 8.0 & 6.0 & 3.0 \\
\hline Bacillus cereus & 10.0 & 4.0 & 4.0 & 3.0 & 2.0 & 1.0 \\
\hline $\begin{array}{l}\text { Staphylococcus } \\
\text { saprophyticus A }\end{array}$ & 14.0 & 5.0 & 4.0 & 4.0 & 2.0 & - \\
\hline $\begin{array}{l}\text { Staphylococcus } \\
\text { saprophyticus B }\end{array}$ & 12.0 & 9.0 & 8.0 & 7.0 & 6.0 & - \\
\hline $\begin{array}{l}\text { Staphylococcus } \\
\text { epidermidis A }\end{array}$ & 10.0 & 8.0 & 7.0 & 7.0 & 6.0 & 3.0 \\
\hline $\begin{array}{l}\text { Staphylococcus } \\
\text { epidermidis B }\end{array}$ & 12.0 & 5.0 & 4.0 & 4.0 & 3.0 & - \\
\hline $\begin{array}{l}\text { Staphylococcus } \\
\text { epidermidis } \mathrm{C}\end{array}$ & 10.0 & 4.0 & 4.0 & 3.0 & 1.0 & - \\
\hline
\end{tabular}

The MIC of the nanoparticles against both the fungi and bacteria pathogens showed a continuous decrease in activity with a reduction in the concentration of the nanoparticles used. This showed that the activity of the nanoparticles is concentration-dependent. This is following
Table 4 MIC of SaAgNPs against selected pathogenic fungi

\begin{tabular}{lcccccc}
\hline & \multicolumn{5}{c}{$\%$ MIC for SaAgNPs } \\
\cline { 2 - 6 } Test Fungi & 100 & 90 & 70 & 50 & 30 & 10 \\
\cline { 2 - 7 } & 9.0 & 6.0 & 4.0 & 3.0 & - & - \\
\hline Candida albicans A & 14.0 & 6.0 & 4.0 & 1.0 & - & - \\
Candida albicans B & 28.0 & 4.0 & 3.0 & - & - & - \\
Candida albicans C & 30.0 & 5.0 & 5.0 & 4.0 & 2.0 & - \\
Rhizopus sp. & 10.0 & - & - & - & - & - \\
Pichia sp. & 30.0 & 4.0 & 4.0 & 3.0 & 2.0 & - \\
Candida tropicalis & 10.0 & 4.0 & 4.0 & 3.0 & 2.0 & - \\
Candida krusei & 14.0 & 8.0 & 8.0 & 3.0 & - & - \\
Trichophyton & & & & & & - \\
interdigitale & & & & & \\
\hline
\end{tabular}

the report of Dubey et al. [54] and Oboh and Abulu [55], who stated that antimicrobial activity is a function of the concentration of the active ingredient that is in contact with the microorganism.

\subsection{Physicochemical property of SaAgNPs-cream blend}

Table 5 shows the $\mathrm{pH}$ and viscosity measurement of the SaAgNPs-cream blend. The $\mathrm{pH}$ SaAgNPs-cream blends were 7.10, 7.26, 7.34 and 5.64 for SaAgNPs-CBa-cream blend (1\%), SaAgNPs-CBb-cream blend (2\%), $\mathrm{AgNO}_{3}$ $\mathrm{CBc}$-cream blend (2\%) and the cream base. The $\mathrm{pH}$ increased to 7.26 when $2 \%$ SaAgNPs was incorporated into the cream base. The viscosity of the SaAgNPs-cream blends at $50 \mathrm{rpm}$ was 21,520, 14,440 cP and 9,060, 6,700, 7800 and 3160 at $100 \mathrm{rpm}$.

The viscosity was reported in a unit of centipoises (cP) and torque. The apparent viscosity and torque were shown about the revolutions per minute (rpm or shear stress) for the formulations. 
Table 5 Viscosity and $\mathrm{pH}$ values of the different cream formulations

\begin{tabular}{|c|c|c|c|c|c|}
\hline \multirow{3}{*}{ Sample name } & \multicolumn{4}{|c|}{ Viscosity } & \multirow{3}{*}{$\mathrm{pH}$} \\
\hline & \multicolumn{2}{|c|}{$50 \mathrm{rpm}$} & \multicolumn{2}{|c|}{$100 \mathrm{rpm}$} & \\
\hline & $\mathrm{cP}$ & $\mathrm{r}$ & $\mathrm{cP}$ & $\mathrm{r}$ & \\
\hline $\begin{array}{l}\text { SaAgNPs-CBa* } \\
(1 \%)\end{array}$ & 21,520 & 27.05 & 9,060 & 22.6 & 7.10 \\
\hline $\begin{array}{l}\text { SaAgNPs- } \\
\mathrm{CBb}^{* *}(2 \%)\end{array}$ & 14,440 & 18.05 & 6,700 & 16.95 & 7.26 \\
\hline $\begin{array}{l}\mathrm{AgNO}_{3}-\mathrm{CBc}^{* * * *} \\
(2 \%)\end{array}$ & - & - & 7800 & - & 7.34 \\
\hline Cream base & - & - & 3160 & - & 5.64 \\
\hline
\end{tabular}

\subsection{Antibacterial and antifungal potential of the SaAgNPs-cream blend}

Table 6 shows the antibacterial activity of the SaAgNPscream blend. The susceptibility of the different bacteria to the cream-blend varies. The cream-blend had antibacterial activity against $68.75 \%$ of the test bacterial isolates while $31.25 \%$ were resistant. The highest antibacterial activity was against Staphylococcus epidermidis B $(7.0 \mathrm{~mm})$ followed by Pseudomonas aeruginosa $27853(6.0 \mathrm{~mm})$. Most of the Staphylococcus aureus A, B, C, and Staphylococcus epidermidis A, B, and $\mathrm{C}$ were susceptible to the SaAgNPscream blend.

Table 7 shows the antifungal activity of the SaAgNPscream blend. The cream-blend had activity against $75 \%$ of the fungal isolates. Candida albicans B had the highest susceptibility $(8.0 \mathrm{~mm})$ follow in order by Pichia $\mathrm{sp}$. $(7.5 \mathrm{~mm})$ and Trichophyton interdigitale (6.0). $25 \%$ of the fungi (Candida albicans A and Rhizopus sp.) were resistant to the SaAgNPs-cream blend.

\section{Conclusions}

Senna alata leaf extract was successfully used for the fabrication of silver nanoparticles and preparation of

\section{References}

[1] Bassetti, M., Righi, E., Carnelutti, A. "New therapeutic options for respiratory tract infections", Current Opinion in Infectious Disease, 29(2), pp. 178-186, 2016.

https://doi.org/10.1097/QCO.0000000000000251

[2] Aminov, R. I. "A Brief History of the Antibiotic Era: Lessons Learned and Challenges for the Future", Frontiers in Microbiology, 1, pp. 1-7, 2010. https://doi.org/10.3389/fmicb.2010.00134

[3] Rai, M., Ingle, A. P., Gaikwad, S., Gupta, I., Gae, A., Silverio da Silva, S. "Nanotechnology based anti-infectives to fight microbial intrusions", Journal of Applied Microbiology, 120(3), pp. 527-542, 2016. https://doi.org/10.1111/jam.13010
Table 6 Antibacterial activity of SaAgNPs-cream blend against the test bacteria

\begin{tabular}{lc}
\hline \multirow{2}{*}{ Test Bacteria } & SaAgNPs-cream blend \\
\cline { 2 - 2 } & Antibacterial activity (mm) \\
\hline Staphylococcus aureus A & 4.0 \\
Staphylococcus aureus B & 3.0 \\
Staphylococcus aureus C & 4.0 \\
Staphylococcus aureus D & - \\
Staphylococcus aureus 29213 & - \\
Eschericia coli 35218 & 5.5 \\
Eschericia coli 11775 & - \\
Pseudomonas aeruginosa 27853 & 6.0 \\
Citrobacter freundii & 1.0 \\
Salmonella typhi 14028 & - \\
Bacillus cereus & 4.0 \\
Staphylococcus saprophyticus A & - \\
Staphylococcus saprophyticus B & 3.0 \\
Staphylococcus epidermidis A & 5.0 \\
Staphylococcus epidermidis B & 7.0 \\
Staphylococcus epidermidis C & 5.0 \\
\hline &
\end{tabular}

Table 7 Antifungal activity of SaAgNPs-cream blend against the

\begin{tabular}{lc}
\multicolumn{2}{c}{ test fungi } \\
\hline Test Fungi & SaAgNPs-cream blend \\
\hline Candida albicans A & - \\
Candida albicans B & 8.0 \\
Candida albicans C & 0.5 \\
Rhizopus sp. & - \\
Pichia sp. & 7.5 \\
Candida tropicalis & 2.0 \\
Candida krusei & 1.0 \\
Trichophyton interdigitale & 6.0 \\
\hline
\end{tabular}

SaAgNPs-cream blends. The SaAgNPs-cream blend had cosmetically acceptable physiochemical parameters. The nanoparticles and the cream blend have antibacterial and antifungal potential against the test isolates and can be used in the preparation of antibacterial and antifungal cream.

[4] Bankalgi, S. C., Londonkar, R. L., Madire, U., Asha Tukappa, N. K. "Biosynthesis, Characterization and Antibacterial Effect of Phenolics-Coated Silver Nanoparticles Using Cassia javanica L.", Journal of Cluster Science, 27(4), pp. 1485-1497, 2016. https://doi.org/10.1007/s10876-016-1016-9

[5] Vijay Kumar, P. P. N., Pammi, S. V. N., Kollu, P., Satyanarayana, K. V. V., Shameem, U. "Green synthesis and characterization of silver nanoparticles using Boerhaavia diffusa plant extract and their anti bacterial activity", Industrial Crops and Products, 52, pp. 562-566, 2014. https://doi.org/10.1016/j.indcrop.2013.10.050 
[6] Chernousova, S., Epple, M. "Silver as Antibacterial Agent: Ion, Nanoparticle, and Metal", Angewandte Chemie International Edition, 52(6), pp. 1636-1653, 2013. https://doi.org/10.1002/anie.201205923

[7] Lim, H. K., Asharani, P. V., Hande, M. P. "Enhanced genotoxicity of silver nanoparticles in DNA repair deficient mammalian cells", Frontiers in Genetics, 3, pp. 1-13, 2012. https://doi.org/10.3389/fgene.2012.00104

[8] Gangula, A., Podila, R., M, R., Karanam, L., Janardhana, C., Rao, A. M. "Catalytic Reduction of 4-Nitrophenol using Biogenic Gold and Silver Nanoparticles Derived from Breynia rhamnoides", Langmuir, 27(24), pp. 15268-15274, 2011. https://doi.org/10.1021/la2034559

[9] Ahmed, S., Saifullah, Ahmad, M., Swami, B. L., Ikram, S. "Green synthesis of silver nanoparticles using Azadirachta indica aqueous leaf extract", Journal of Radiation Research and Applied Sciences, 9(1), pp. 1-7, 2016. https://doi.org/10.1016/j.jrras.2015.06.006

[10] Ravichandran, V., Vasanthi, S., Shalini, S., Shah, S. A. A., Harish, R. "Green synthesis of silver nanoparticles using Atrocarpus altilis leaf extract and the study of their antimicrobial and antioxidant activity", Materials Letters, 180, pp. 264-267, 2016.

https://doi.org/10.1016/j.matlet.2016.05.172

[11] Francis, S., Joseph, S., Koshy, E. P., Mathew, B. "Green synthesis and characterization of gold and silver nanoparticles using Mussaenda glabrata leaf extract and their environmental applications to dye degradation", Environmental Science and Pollution Research, 24(21), pp. 17347-17357, 2017.

https://doi.org/10.1007/s11356-017-9329-2

[12] Paosen, S., Saising, J., Septama, A. W., Voravuthikunchai, S. P. "Green synthesis of silver nanoparticles using plants from Myrtaceae family and characterization of their antibacterial activity", Materials Letters, 209, pp. 201-206, 2017. https://doi.org/10.1016/j.matlet.2017.07.102

[13] Shankar, S., Leejae, S., Jaiswal, L., Voravuthikunchai, S. P. "Metallic nanoparticles augmented the antibacterial potency of Rhodomyrtus tomentosa acetone extract against Escherichia coli", Microbial Pathogenesis, 107, pp. 181-184, 2017. https://doi.org/10.1016/j.micpath.2017.03.036

[14] Kolawole, R. M., Thomas, B. T., Folorunso, J. B., Oluwadun, A. "GC-MS Analysis and antifungal activity of Senna alata Linn", International Journal of Microbiological Research, 6(2), pp. 100-107, 2015.

https://doi.org/10.5829/idosi.ijmr.2015.6.2.93167

[15] Kavipriya, K., Chandra, M. "FTIR and GCMS Analysis of Bioactive Phytocompounds in Methonalic Leaf Extract of Cassia Alata", Biomedical and Pharmacology Journal, 11(1), pp. 141-147, 2018. https://oi.org/10.13005/bpj/1355

[16] Hennebelle, T., Weniger, B., Joseph, H., Sahpaz, S., Bailleul, F. "Senna alata", Fitoterapia, 80(7), pp. 385-393, 2009. https://doi.org/10.1016/j.fitote.2009.05.008
[17] Chomnawang, M. T., Surassmo, S., Wongsariya, K., Bunyapraphatsara, N. "Antibacterial Activity of Thai Medicinal Plants against Methicillin-resistant Staphylococcus aureus", Fitoterapia, 80(2), pp. 102-104, 2009. https://doi.org/10.1016/j.fitote.2008.10.007

[18] Quattrocchi, U. "CRC World Dictionary of Medicinal and Poisonous Plants", CRC Press,Boca Raton, New York, NY, USA, 2012, pp. 236-237.

https://doi.org/10.1201/b16504

[19] Wikaningtyas, P., Sukandar, E. Y. "The antibacterial activity of selected plants towards resistant bacteria isolated from clinical specimens", Asian Pacific Journal of Tropical Biomedicine, 6(1), pp. 16-19, 2016.

https://doi.org/10.1016/j.apjtb.2015.08.003

[20] Timothy, S. Y., Wazis, C. H., Adati, R. G., Maspalma, I. D. "Antifungal Activity of Aqueous and Ethanolic Leaf Extracts of Cassia alata Linn", Journal of Applied Pharmaceutical Science, 2(7), pp. 182-185, 2012. https://doi.org/10.7324/JAPS.2012.2728

[21] Reezal, I, Somchit, M. N., Abdul Rahim, M. "In vitro Antifungal Properties of Cassia alata (Gelenggang Besar)", In: Proceedings of the Regional Symposium on Environment and Natural Resources,Kuala Lumpur, Malaysia, 2002, pp. 654-659.

[22] Damodaran, S., Venkataraman, S. "A study on the therapeutic efficacy of Cassia alata, Linn. leaf extract against Pityriasis versicolor", Journal of Ethnopharmacology, 42(1), pp. 19-23, 1994. https://doi.org/10.1016/0378-8741(94)90018-3

[23] Kundu, S., Roy, S., Lyndem, L. M. "Cassia alata L: potential role as an anthelmintic agent against Hymenolepis diminuta", Parasitology Research, 111, pp. 1187-1192, 2012. https://doi.org/10.1007/s00436-012-2950-6

[24] Joshi, S. G. "Medicinal Plants", Oxford and IBH Publishing Company, New Delhi, India, 2000.

[25] Gaddam, S. A., Kotakadi, V. S., Sai Gopal, D. V. R., Subba Rao, Y., Varada Reddy, A. "Efficient and robust biofabrication of silver nanoparticles by Cassia alata extract and their antimicrobial activity", Journal of Nanostructure and Chemistry, 4(1), Article number: 82, 2014.

https://doi.org/10.1007/s40097-014-0082-5

[26] Sule, W. F., Okonko, I. O., Omo-Ogun, S., Nwanze, J. C., Ojezele, M. O., Ojezele, O. J., Alli, J. A., Soyemi, E. T., Olaonipekun, T. O. "Phytochemical properties and in-vitro antifungal activity of Senna alata Linn. crude stem bark extract", Journal of Medicinal Plants Research, 5(2), pp. 176-183, 2011. [online] Available at: https://academicjournals.org/journal/JMP/ Rarticle-abstract/9B9A6E818119 [Accessed: 27 March 2021]

[27] Vijayakumari, A., Sinthiya, A. "Biosynthesis of Phytochemicals Coated Silver Nanoparticles Using Aqueous Extract of Leaves of Cassia alata - Characterization, Antibacterial and Antioxidant Activities", International Journal of Pharmaceutical and Clinical Research, 10(5), pp. 138-149, 2018. 
[28] Ontong, J. C., Paosen, S., Shankar, S., Voravuthikunchai, S. P. "Eco-friendly synthesis of silver nanoparticles using Senna alata bark extract and its antimicrobial mechanism through enhancement of bacterial membrane degradation", Journal of Microbiological Methods, 165, Article number: 105692, 2019.

https://oi.org/10.1016/j.mimet.2019.105692

[29] Kareru, P. G., Keriko, J. M., Kenji, G. M., Thiong'o, G. T., Gachanja, A. N., Mukiira, H. N. "Antimicrobial activities of skincare preparations from plant extracts", African Journal of Traditional, Complementary and Alternative Medicines, 7(3), pp. 214-218, 2010.

https://doi.org/10.4314/ajtcam.v7i3.54777

[30] Senga, K. P., Nkanga, I. C., Ngoro, V., Welo, U. J., Opota, O. D. "Formulation Of a Herbal Dermal Ointment Using Whole Leaves Of Cassia Alata Linn", International Journal of Ayurvedic and Herbal Medicine, 6(6), pp. 2355-2363, 2016. [online] Available at: http://www.interscience.org.uk [Accessed: 27 March 2021]

[31] Majekodunmi, S. O., Essien, A. A. "Development and evaluation of antimicrobial herbal formulations containing the methanolic extract of Cassia alata for skin diseases", Journal of Coastal Life Medicine, 2(11), pp. 872-875, 2014.

https://doi.org/10.12980/JCLM.2.201414D93

[32] Esimone, C. O., Nworu, C. S., Ekong, U. S., Okereke, B. "Evaluation of the antiseptic properties of Cassia alata-based herbal soap", The Internet Journal of Alternative Medicine, 6(1), pp. 117-124, 2008.

[33] Mansfield, E., Tyner, K. M., Poling, C. M., Blacklock, J. L. "Determination of Nanoparticle Surface Coatings and Nanoparticle Purity Using Microscale Thermogravimetric Analysis", Analytical Chemistry, 86(3), pp. 1478-1484, 2014.

https://doi.org/10.1021/ac402888v

[34] Adebayo-Tayo, B. C., Borode, S. O., Olaniyi, O. A. "Phytosynthesis of zinc oxide nanoparticles using methanol extract of Senna alata leaf: Characterization, optimization, antimicrobial properties, and its application in cold cream formulation", Polimers in Medicine, 50(1), pp. 5-19, 2020 https://doi.org/10.17219/pim/122901

[35] Suliman, R. S., Ali, H., Nurulain, I., NurShamiha, N., Nizam, M., Budiasih, S., Suliman, R., Al-Gebaly, A. "Cinnamon bark extract for the formulation and characterization of antimicrobial cream", International Journal of Research in Ayurveda and Pharmacy, 8(Suppl 2), pp. 200-206, 2017. https://doi.org/10.7897/2277-4343.082113

[36] Balouiri, M., Sadiki, M., Ibnsouda, S. K. "Methods for in vitro evaluating antimicrobial activity: A review", Journal of Pharmaceutical Analysis, 6(2), pp. 71-79, 2016.

https://doi.org/10.1016/j.jpha.2015.11.005

[37] Vigneshwaran, N., Ashtaputre, N. M., Varadarajan, P. V., Nachane, R. P., Paralikar, K. M., Balasubramanya, R. H. "Biological synthesis of silver nanoparticles using the fungus Aspergillus flavus", Materials Letters, 61(6), pp. 1413-1418, 2007. https://doi.org/10.1016/j.matlet.2006.07.042

[38] Adebayo-Tayo, B. C., Akinsete, T. O., Odeniyi, O. A. "Phytochemical Composition and Comparative Evaluation of Antimicrobial Activities of the Juice Extract of Citrus Aurantifolia and its Silver Nanoparticles", Nigerian Journal of Pharmaceutical Research, 12(1), pp. 59-64, 2016.
[39] Balashanmugam, P., Balakumaran, M. D., Murugan, R., Dhanapal, K., Kalaichelvan, P. T. "Phytogenic synthesis of silver nanoparticles, optimization and evaluation of in vitro antifungal activity against human and plant pathogens", Microbiological Research, 192, pp. 52-64, 2016. https://doi.org/10.1016/j.micres.2016.06.004

[40] Krishnaraj, C., Jagan, E. G., Ramachandran, R., Abirami, S. M., Mohan, N., Kalaichelvan, P. T. "Effect of biologically synthesized silver nanoparticles on Bacopa monnieri (Linn.) Wettst. plant growth metabolism", Process Biochemistry, 47(4), pp. 651-658, 2012.

https://doi.org/10.1016/j.procbio.2012.01.006

[41] Nickel, U., zu Castell, A., Pöppl, K., Schneider, S. "A Silver Colloid Produced by Reduction with Hydrazine as Support for Highly Sensitive Surface-enhanced Raman spectroscopy", Langmuir, 16(23), pp. 9087-9091, 2000. https://doi.org/10.1021/la000536y

[42] Shukla, A., Makwana, B. A. "Facile Synthesis of Silver Nanoparticle and Their Potential Application", American Journal of Nanoscience and Nanotechnology, 2(4), pp. 84-92, 2014. https://doi.org/10.11648/j.nano.20140204.14

[43] Borase, H. P., Salunke, B. K., Salunke, R. B., Patil, C. D., Hallsworth, J. E., Kim, B. S., Patil, S. V. "Plant Extract: A Promising Biomatrix for Ecofriendly, Controlled Synthesis of Silver Nanoparticles", Applied Biochemistry and Biotechnology, 173(1), pp. 1-29, 2014.

https://doi.org/10.1007/s12010-014-0831-4

[44] Udayasoorian, C., Kumar, V. K., Jayabalakrishnan, R. M. "Extracellular synthesis of silver nanoparticles using leaf extract of Cassia auriculata", Digest Journal of Nanomaterials and Biostructures, 6(1), pp. 279-283, 2011.

[45] Sintubin, L., Verstraete, W., Boon, N. "Biologically produced nanosilver: Current state and future perspectives", Biotechnology and Bioengineering, 109(10), pp. 2422-2436, 2012. https://doi.org/10.1002/bit.24570

[46] Deshmukh, A. R., Gupta, A., Kim, B. S. "Ultrasound Assisted Green Synthesis of Silver and Iron Oxide Nanoparticles Using Fenugreek Seed Extract and Their Enhanced Antibacterial and Antioxidant Activities", BioMed Research International, pp. 1-14, 2019.

https://doi.org/10.1155/2019/1714358

[47] Singh, A. K., Viswanath, V., Janu, V. C. "Synthesis, effect of capping agents, structural, optical and photoluminescence properties of $\mathrm{ZnO}$ nanoparticles", Journal of Luminescence, 129(8), pp. 874-878, 2009.

https://doi.org/10.1016/j.jlumin.2009.03.027

[48] Chitsazi, M. R., Korbekandi, H., Asghari, G., Najafi, R. B., Badii, A., Iravani, S. "Synthesis of silver nanoparticles using methanol and dichloromethane extracts of Pulicaria gnaphalodes (Vent.) Boiss. aerial parts", Artificial Cells, Nanomedicine, Biotechnology, 44(1), pp. 328-333, 2016. https://doi.org/10.3109/21691401.2014.949726

[49] Raliya, R., Tarafdar, J. C. "Biosynthesis and characterization of zinc, magnesium and titanium nanoparticles: an eco-friendly approach", International Nano Letters, 4(1), Article number: 93, 2014. https://doi.org/10.1007/s40089-014-0093-8 
[50] Thema, F. T., Manikandan, E., Dhlamini, M. S., Maaza, M. "Green synthesis of $\mathrm{ZnO}$ nanoparticles via Agathosma betulina natural extract", Materials Letters, 161, pp. 124-127, 2015. https://doi.org/10.1016/j.matlet.2015.08.052

[51] Sarsar, V., Selwal, M. K., Selwal, K. K. "Biofabrication, characterization and antibacterial efficacy of extracellular silver nanoparticles using novel fungal strain of Penicillium atramentosum KM", Journal of Saudi Chemical Society, 19(6), pp. 682-688, 2015. https://doi.org/10.1016/j.jscs.2014.07.001

[52] Fayaz, A. M., Balaji, K., Girilal, M., Yadav, R., Kalaichelvan, P. T., Venketesan, R. "Biogenic synthesis of silver nanoparticles and their synergistic effect with antibiotics: a study against gram-positive and gram-negative bacteria", Nanomedicine: Nanotechnology, Biology and Medicine, 6(1), pp. 103-109, 2010

https://doi.org/10.1016/j.nano.2009.04.006
[53] Mallmann, E. J. J., Cunha, F. A., Castro, B. N.M. F., Maciel, A. M., Menezes, E. A., Fechine, P. B. A. "Antifungal activity of silver nanoparticles obtained by green synthesis", Revista do Instituto de Medicina Tropical de São Paulo, 57(2), pp. 165-167, 2015. https://doi.org/10.1590/S0036-46652015000200011

[54] Dubey, S. P., Lahtinen, M., Sillianpää, M. "Tansy fruit mediated greener synthesis of silver and gold nanoparticles", Process Biochemistry, 45(7), pp. 1065-1071, 2010. https://doi.org/10.1016/j.procbio.2010.03.024

[55] Oboh, P. A., Abulu, E. O. "The antimicrobial activities of extracts of Sidium guajava and Citrus aurantifolia", Nigerian Journal of Biotechnology, 8(1), pp. 25-29, 1997. 